Inflation of the chest with high intrathoracic pressures inevitably results in gastric distension with an unacceptable increase in the chance of vomiting. This problem may be overcome with the use of a cuffed endotracheal tube or perhaps an obturator airway in the oesophagus ${ }^{7}$ - provided that an adequate seal is made with the mask at the face.

1 Nolte H. A new evaluation of emergency methods for artificial ventilation. Acta Anaesthesiol Scand 1968;29, suppl:111-25.

2 Kouwenhoven WB, Jude JR, Knickerbocker GG. Closed-chest cardiac massage. FAMA 1960;173:1064-7.

${ }^{3}$ MacKenzie GJ, Taylor SH, McDonald AH, Donald KW. Haemodynamic effects of external cardiac compression. Lancet 1964 ;ii :1342-5.

4 Rudikoff MT, Maughan WL, Effron M, Freund P, Weisfeldt ML. Mechanisms of blood flow during cardiopulmonary resuscitation. Circulation 1980;61:345-52.

- Chandra N, Rudikoff M, Weisfeldt ML. Simultaneous chest compression and ventilation at high airway pressure during cardiopulmonary resuscitation. Lancet $1980 ; \mathrm{i}: 175-8$.

- Taylor GJ, Tucker WM, Greene HL, Rudikoff MT, Weisfeldt ML. Importance of prolonged compression during cardiopulmonary resuscitation in man. N Engl F Med 1977;296:1515-7.

7 Don Michael TA, Hotfon AS. The oesophageal obturator airway: a new device in emergency cardiopulmonary resuscitation. $\mathrm{Br} M e d \mathcal{F} 1980$; 281:1531-4.

\section{Bronchial adenomas}

Bronchial adenomas form a heterogeneous group accounting for somewhere between $1 \%$ and $6 \%$ of all primary lung tumours. $^{1-4}$ They are a continuing source of error and confusion in diagnosis. Though traditionally regarded as benign, more realistically they should be viewed as tumours of varying degrees of low-grade malignancy. Adenomas are derived from the duct epithelium of bronchial mucous glands and are usually either carcinoids or tumours of salivary-gland type.

Carcinoids account for about $90 \%$ of most series ${ }^{4-6}$ and generally arise centrally in the trachea or main bronchi. Often they present with features of an endobronchial polyp, but extensive infiltration of surrounding lung is common. The characteristic features seen with gut carcinoids-cyanotic flushing, abdominal cramps, diarrhoea, oedema of the face and arms, and wheezing and dyspnoea-are rare with primary lung tumours, occurring in only about $2 \%$ of cases. ${ }^{5}$ When the heart valves are affected by primary lung carcinoids the lesions occur in the left heart ${ }^{2}$ rather than in the right heart, as with gut carcinoids and secondary deposits.

About two-thirds of the tumours of the salivary-gland type are cylindromas. Typically these, too, are central tumours, often encircling the airway and infiltrating extensively into surrounding lung. They are second only to primary carcinomas in incidence as tumours of the trachea. Most of the remainder of the salivary-gland tumours are mucoepidermoid adenomas. Pleomorphic adenomas, resembling mixed parotid tumours, are very rare.

Bronchial adenomas usually present for diagnosis at a much earlier age than carcinomas, commonly before the age of 50,48 and the sex incidence is more nearly equal. Cough and haemoptysis are the first symptoms in around half the patients; often the chest radiograph is normal at that time. Another common pattern of presentation is with infection distal to obstruction by the tumour, causing lobar or segmental collapse and occasionally bronchiectasis, lung abscess, or empyema. Obstructive emphysema with overinflation of a segmental lobe may also occur distal to an adenoma. Peripheral adenomas tend to declare themselves much later and may be discovered as an incidental finding on chest radiography.
Early diagnosis of this group of tumours is essential if local destructive damage and distant metastases are to be avoided. Suspicion should be aroused in any patient with haemoptysis or recurrent chest infections, especially with a normal chest radiograph. Since almost all these tumours are visible at bronchoscopy this is the investigation of choice, but caution is necessary: many have a highly vascular stroma and bleed profusely on biopsy. If fibreoptic bronchoscopy is used an endotracheal tube or rigid bronchoscope must immediately be available to deal with bleeding.

Whenever feasible the treatment of bronchial adenoma is surgical. ${ }^{4}$ Sleeve resection of the tumour may sometimes be possible, but lobectomy or even pneumonectomy may be necessary because of extensive spread. Favourable responses to radiotherapy have been reported with cylindromas regarded as unresectable. ${ }^{910}$ Where the primary tumour can be resected the prognosis is good: prolonged survival is possible even with distant metastases, because these tumours grow so slowly.11

1 Gibbons JH, Nealon TF. Neoplasms of the lungs and trachea. In: Gibbons JH, ed. Surgery of the chest. Philadelphia: WB Saunders, 1962. 2 Thompson VC. Tumours of the lung. In: Perry KMA, Sellors TH, eds. Chest diseases. Vol 2. London: Butterworth, 1963.

3 Arrigoni MG, Woolmer LB, Bernatz PE, Miller WE, Fontana RS. Benign tumours of the lung. A ten-year surgical experience. $f$ Thorac Cardiovasc Surg 1970;60:589-99.

4 Lawson RM, Ramanathan L, Hurley G, Hinson KW, Lennox SC. Bronchial adenoma: review of 18-year experience at the Brompton Hospital. Thorax $1976 ; 31: 245-53$.

5 Payne WS, Fontana RS, Woolner LB. Bronchial tumours originating from mucous glands. Current classification and unusual manifestations. Med Clin North Am 1964;48:945-60.

${ }^{6}$ Markel SF, Abell MR, Haight C, French AJ. Neoplasms of bronchus commonly designated as adenomas. Cancer 1964;17:590-608.

${ }^{7}$ Melmon KL, Sjoerdsma A, Mason DT. Distinctive clinical and therapeutic aspects of the syndrome associated with bronchial carcinoid tumours. Am $\mathcal{F}$ Med $1965 ; 39: 568-81$.

8 Bower G. Bronchial adenomas. A review of twenty-eight cases. Am Rev Respir Dis 1965;92:558-63.

9 Thomas CP. Benign tumours of the lung. Lancet 1954 ;i:1-7.

10 Vieta JO, Maier HC. The treatment of adenoid cystic carcinoma (cylindroma) of the respiratory tract by surgery and radiation therapy. Diseases of the Chest $1957 ; 31: 493-511$.

11 Zellos S. Bronchial adenoma. Thorax 1962;17:61-8.

\section{Improving the surgical management of biliary atresia}

For the infant with biliary atresia the only hope of prolonged survival lies in early diagnosis and effective surgery. The diagnosis must be considered in any infant in the first weeks of life who becomes jaundiced with dark, bile-containing (as opposed to normal, colourless) urine. Such infants always have some hepatobiliary disease; they have a high risk of intracranial bleeding from lack of vitamin $\mathrm{K}$, and require urgent investigation to exclude treatable conditions such as galactosaemia or septicaemia. When these and other common genetic causes, such as alpha-1-antitrypsin deficiency, have been excluded and the stools lack bile pigment biliary atresia becomes a distinct possibility.

To what extent is biliary atresia treatable surgically? A review by Psacharopoulos and co-workers ${ }^{1}$ of 47 consecutive infants operated on by one surgeon at King's College Hospital, London, from July 1973 to December 1978, reported 17 survivors aged between 3 and 65 months who were symptomfree with normal growth and normal serum concentrations 